\title{
The Law Enforcement of The Abuse of Alcohol With Methanol Mixture
}

\author{
Sri Wulandari ${ }^{\text {la }}$, Bambang Teguh Handoyo ${ }^{1 \mathrm{~b}}$ \\ ${ }^{1}$ Faculty of Law, University of 17 Agustus 1945 Semarang, Indonesia \\ a ndari904@gmail.com, ${ }^{b}$ bambangteguhhandoyo@gmail.com
}

\begin{abstract}
Most of Indonesians consume alcohol/liquor. Ironically many people mix the liquor with variety of drinks or drugs with hazardous materials (methanol) so the effect is more intoxicating with cheap price which can affect the physical, spiritual and social behavior of a person until death. Liquor cases are problems that are not easily resolved, every year there is an increase in the number of victims of consuming/abusing the mixed liquor. The existence of Presidential Regulation No.74 of 2013 which limits and controls the distribution of alcohol is deemed ineffective. Most of the rules regarding alcohol are still technical, if there are violations not subject to criminal sanctions only administrative sanctions and if there is a legal process only subjected to Health Law, Food Law and Consumers Protection Law. This research uses a qualitative descriptive method with data collection tools in the form of open and closed questionnaires. The subjects in this study are stakeholders (law enforcement officials and local government) as well as the community (producers, sellers and consumers of mixed liquor) with snow ball sampling techniques, the research locations are in the Semarang City and Grobogan Regency. The results of this study are to reveal the habits of the community in producing, selling, consuming and mixing with alcoholic beverages with various drugs and hazardous materials (methanol) and the effectiveness of law enforcement as well as Regional Regulations in controlling against the distribution of liquor through strengthening the substance, structure and culture of law by using the means of reasoning, non-reasoning and local wisdom. It is hoped that it can foster public awareness of the dangers of mixed liquor abuse, then the producers and sellers of alcoholic beverages can be given maximum punishment to provide a deterrent effect.
\end{abstract}

Keywords-Alcoholic Beverages, Mixed Liquor Abuse, Law Enforcement

\section{INTRODUCTION}

Alcoholic beverages are beverage containing ethyl alcohol or ethanol $(\mathrm{C} 2 \mathrm{H} 5 \mathrm{OH})$, which are processed from agricultural products containing carbohydrates by fermentation and distillation or fermentation without distillation (Article 1 section (1) Presidential Regulation of Republic of Indonesia No. 74 of 2013). While the traditional alcoholic beverages are made traditionally and hereditary that is packaged simply and the manufacture is done at any time, and used for the needs of customs or religious events [7].

In Indonesia, alcoholic beverages are divided into several categories according to their ethanol content, those are class A with ethanol content of $1 \%$ to $5 \%$, class B with ethanol content of $5 \%$ to $20 \%$ and class C more than $20 \%$ up to $55 \%$. There are also liquor that produced traditionally/hereditary such as Arak (Arrack), Ciu (alcohol from the process of fermentation of liquid cassava), Ginseng and Palm wine.

Alcoholic beverages have been integrated into the lives of Indonesians, although the distribution of alcoholic beverages is controlled by the state especially imported beverages (Regulation of Ministry of Trade of Republic of Indonesia No. 15/M-DAG/PER/3/2006) and tightened in terms of licensing, but there are still many parties who take advantage with no regard to the risk factors of illicit alcoholic/alcoholic beverages.
The existence of alcohol will not be harmful if it intends properly, even in some areas in Indonesia often used in a cultural ritual for wedding ceremonies or religious events and provide a high enough income for local government in the form of taxes of alcoholic beverages.

Alcohol/liquor abuse is a very complex and not easily solved problem ranging from collectors, sellers to users, from time to time many casualties are wasted, ironically they consume alcohol/liquor by way of mixing that is mixing alcoholic beverages with soft drink, drugs, lotions, mosquito repellent and chemicals (methanol) just to get the effect of more intoxicating at a low price without considering health risk factors and fatal.

The phenomenon of alcoholic beverage abuse, or better known in Indonesia as Miras Oplosan, is always repeated, generally victims in the productive age (20 to 50 years old) and from the middle to lower class. By consuming alcohol they hope to get excitement, eliminate low self-esteem and just looking for attention. Victims of alcoholic beverages fall and cause a lot of damage in the social order in society.

Community awareness/participation in suppressing abuse of illegal mixed liquor distribution will make the liquor seller or drunkard feel uncomfortable, so it is necessary firmness the law enforcement from government/authorities to act immediately by giving the punishment that weighs in to give the deterrent effect while the chemical substances (methanol) which are often used for mixing the liquor need to be 
monitored/tightened the circulation in order to narrow the access space to the wider community.

The use of toxic chemicals such as methanol does not only adversely affect the safety of the human psyche but also causes public unrest and disrupts security and public order. So the government is responsible in planning, organizing, providing, fostering, supervising and controlling in a form of regulation of liquor, as well as efforts to harmonize and optimize the Regional Regulation.

Meanwhile, the existence of Presidential Regulation No. 74 of 2013 which gives authority to Local Government to limit and control the distribution of liquor is not effective. Most liquor rules are technical, if there is a violation the perpetrator is not subject to criminal sanction, only if there is a legal process the perpetrator is only charged with the Health Law, Food Law and Consumer Protection Law with very light punishment that is not proportional to his criminal act.

\section{RESEARCH METHOD}

This research used descriptive qualitative method. Descriptive research is a research that aims to explore, clarify, describe the state of the object or subject of a person's research, institution or society systematically, factually and accurately about a phenomenon or social reality, facts, usefulness and relationships between phenomena investigated by the way describe a number of variables relating to the problem under study. Whereas in qualitative research, the theory is interpreted as a paradigm.

The reason for choosing a descriptive approach is to use the presentation directly about social symptoms based on indicators about the presence or absence of a symptom under study (Slamet, 2006: 7) regarding the nature of the relationship of law enforcement with abuse of mixed liquor. Furthermore, to find out the deviant behavior of people using mixed liquor that uses hazardous chemical materials (methanol) among the middle to lower classes.

The informant in this research was taken by snowball sampling, which is the technique of determining the sample which was originally small and then enlarged. The informants in this study were law enforcement officers (Indonesian National Police), local governments and producing communities, sellers and abusers of mixed liquor aged 20-50 years. Using primary data and secondary data, data collection is done with open and closed questionnaires and interviews based on the initial data that the author got before.

This research took place in Semarang City and Grobogan Regency, arguing that even though the city of Semarang was the capital of the province of Central Java, but there were many people in two locations, East Semarang and North Semarang still sell the alcoholic beverages undisguised. Researchers want to see and know what is happening in the community in relation to their social life. Whereas in Grobogan Regency (Kradenan village) the people traditionally/hereditary make white wine and $\mathrm{Ciu}$ which is intended as a mixture of herbs (warmers). There are also those who abuse as a mixture of liquor. The author considers that the problem of abuse of mixed liquor is a serious and interesting issue and it is not easily resolved starting from collectors, sellers to consumers so that a strict law enforcement process is needed through the efforts of reasoning, non-reasoning and local wisdom considering the victims of alcoholic beverages. It is not just impacting on health but also having fatal/dead effects are also very influential on one's social life and disrupt public order.

\section{SCOPE OF LIQUOR/MIXED LIQUOR}

Liquor is any type of drinks that contain addictive substance (alcohol) but not a drug, which includes class A, class B and class C. Liquor/alcoholic beverages class B and class C belonging to a group of liquors which production, importation, distribution and sales are designated as goods under control (Article 7 section (1) Presidential Regulation $74 / 2013$. Sales are only allowed at:

1. Star hotels 3, 4 and 5;

2. Restaurants with Talam Kencana and Talam Selaka signs;

3. Bar includes Pab and nightclub.

For certain regions that do not have the place as mentioned above taking into account the activities of foreign tourists in their region can establish a certain place located in the capital district/city.

Direct sales of alcoholic beverages of class A, B and C are only allowed to make sales based on the time and conditions of life of the local community. Everyone is prohibited from selling retail alcoholic beverages of class A, $\mathrm{B}$ and $\mathrm{C}$ except to those Indonesian citizens who are 21 years old by showing their Identity Card (Article 15 of Regulation of Ministry of Trade of Republic of Indonesia 20/2014) and adult foreign citizens. Any company violating such provision shall be liable to administrative sanctions in the form of a written warning to the revocation of a Business License, as stipulated in Article 17 of Regulation of Ministry of Trade of Republic of Indonesia No. 15. Distributor appointed by producer or importer shall meet the following requirements:

a. Incorporated,

b. Having a Business License,

c. Have/Master the warehouse storage of liquor,

d. Having experienced in the distribution of liquor for at least 2 years,

e. Be well behaved, have high responsibility and dedication in implementing the provisions of alcohol/liquor distribution rules.

As for industrial business license, supervision of alcoholic beverage business is traditionally carried out by the Governor/Head of Region Level I based on the guideline stipulated by the Minister of Industry and Trade.

The distribution of alcoholic beverages/liquor today is quite apprehensive, although it has been tightened in terms of administrative licensing, but liquor can be found easily in certain places that are deliberately sold even the buyer is not limited by age. Ironically, people who are not satisfied with a certain amount of alcohol and then mixing it with various drugs/chemicals such as methanol to give more intoxicating with cheap price even can endanger health, affect behavior, way of thinking and someone's social life.

Quoted by [11] that, at this time many people abuse alcohol to increase self-confidence, brave and assume all 
problems can be overcome, by drinking liquor will add friends. Deviant behavior in the abuse of liquor does not just happen without any pulling and pushing factors, from inside and outside of someone. Following are the factors that cause alcohol abuse is increasing to increase, such as:

1. Unemployment

The problem of unemployment often makes a person frustrated and makes life meaningless and can even lead to a dark life like consuming alcohol

The informant said that they consume alcohol only as an escape to cover their irritation because of the difficulty of getting a job and having fun with friends. Even some of them say that they consume alcohol because of being forced.

2. Promiscuity

Promiscuity is often identified with relationships beyond the limits of reason due to the era of globalization that can easily attack the aspects and joints of people's lives.

For example, because of the curiosity to consume liquor, starting from trying, it becomes a habit or because of an invitation from a close friend or brother.

3. Enjoyment

Liquor has its own enjoyment for the consumer, except for those who are accustomed to consuming liquor and even can make the drinker feel confident, brave, happy, calm his mind like hovering, friendship becomes strong, feelings of shame are reduced and pleasant/happy.

Based on information from the field observations that enjoyment is one of the drivers of someone consuming alcohol can make the drinker addicted and want to consume alcohol repeatedly accompanied by increasing alcohol levels which have more intoxicating effects (Agung, 2015: 66).

The danger of out-of-control behavior causes them to abuse alcohol by mixing various kinds of drinks and drugs to the use of chemicals such as methanol. Methanol $(\mathrm{CH} 3 \mathrm{OH})$ chemical substances are often misused / mixed into liquor which is actually intended as industrial solvents and raw materials for the production of chemicals not for human consumption, methanol is volatile, flammable and toxic, while what can be consumed in alcoholic beverages is ethanol $(\mathrm{C} 2 \mathrm{H} 5 \mathrm{OH})$. Ethanol and methanol are liquids that sound the same characteristics of appearance and smell. But both are very different and if one is wrong in placing or doing ethanol/methanol, it can be a fatal mistake [12].

Therefore, those who circulate alcohol must be controlled tightly for no mistake in labeling because the abuse of mixed liquor using methanol is very dangerous for drinkers [13].

Methanol is often misused as the main ingredient of mixed liquor. It shows the rise of hazardous substances that are still circulating freely without control. As a result, methanol which should be used as the main ingredient of the industry is misused as a food for liquor. In addition to the lack of control over methanol hazardous materials, there is also a lack of public understanding regarding the dangers of mixed liquor which makes the problem more complex. Therefore, a regulation is needed to regulate the circulation of methanol so that it is not prone to being misused, although its presence is needed but its use needs to be monitored. The public must also be given the understanding that alcoholic beverages with methanol are very dangerous and toxic.

Liquor is widely distributed and consumed by many people in Semarang City and in Grobogan Regency due to many illegal liquor sellers. Generally, liquor seller do not have an official permit to sell liquor and the weak control of related parties results in liquor consumers being able to easily get what they want or even buyers are not limited by age and time of sale.

As stated by a subject consuming alcohol or often referred to as ginseng drink, that he was used to consume ginseng when he was a teenager (20 years) but he did not know what was in the ginseng drink and realized that ginseng was taken with methanol after seen the news shows on television. Although the subject is actually very aware of the effects after drinking mixed liquor, such as his chest feels hot, blurred vision and limp body.

In reality the abuse of alcoholic beverages is inseparable from the culture of society which often makes the production of traditional liquor (white wine, Ciu, Ginseng and Palm wine) as a source of the economy to gain profit without thinking of danger. Based on fact in Kradenan-Purwodadi village in Grobogan Regency, according to informants and data in the field that the people in Kradenan village traditionally/hereditary are accustomed to processing and consuming white wine to be used as a mixture of medicine and stamina/health enhancer. Even some have made activities to produce white wine as a home business to increase the source of the family's economy.

At the beginning, the process of the abuse of mixed liquor carried out by the subjects in this study was influenced by friends and the environment. The conformity to groups is one of the social and cultural factors that cause alcoholic drinking behavior. Pressure in the form of coercion and invitations made the subject reluctant to refuse the invitation to consume alcoholic beverages.

As explained by the informant in the KradenanPurwodadi village Grobogan Regency, not a few people who mix Ciu, Ginseng, white wine, lotions, various drinks and chemicals (methanol) will get a better taste as well as to anticipate the expensive price of liquor that is not affordable for them. In addition, there arises a belief from the subject that by abusing alcoholic beverages will be able to fulfill their hopes of relieving stress and being accepted by their environment.

Most of the informants in this study said that the negative psychological and physical effects of mixed liquor had been realized by the subject that would damage the body's organs, make the head dizzy, addicted, weak, and drunk, also more fatal damage to vital organs such as the heart, the kidney reaches blindness and dies.

Peggi (Holistik Journal, Year VIII No. 16/July-December 2005, p.7) stated that consuming alcohol is a form of social deviation that not only arises when there are no pulling and pushing factors. There are some of the most influential factors, namely):

a. Individual Factors

There is a desire to prove to break away from problems, find the meaning of life and a sense of solidarity with friends. Besides being driven by curiosity, courage is 
also urged by the turmoil of his soul who wants to be considered great, brave and as a hero among his friends.

b. Family Factor

Family conflict or lack of harmony and poor communication in one family can make family members feel frustrated and drink alcohol as a solution to escape and trigger of alcohol abuse.

c. Environmental factor

An unfavorable environment always provides an opportunity for them to get to know something bad like liquor, both from curiosity, trial and error, consuming to the level of alcoholism accompanied by a strong sense of solidarity.

d. Religion Factors

Religious education is a major factor that is needed and influences the behavior of a person's mental development that will form a good and bad personality.

e. Educational Factors

Good education greatly influences the way a person thinks to determine what is good and bad.

Abuse of liquor will have bad impact for health, physical and psychological. While the signs caused by the use of alcohol and hazardous chemicals (methanol) will lead to courage that leads to a violent behavior, angry, easily offended and acts brutally which leads to criminal acts / law violations that can ultimately cause anxiety and problems with others and disrupt public order. So that there needs to be synchronization in the control of alcoholic beverages between law enforcement with the Regional Government through strengthening the substance, structure and culture of law and emphasizing on aspects of intense socialization, synergy and communication while fostering and streamlining public awareness of the dangers of alcohol abuse.

The case of alcohol abuse is not an easy issue to solve every year, there is an increase in casualties of alcoholism that worries more easily they can get mixed liquor in certain places that are deliberately sold and the buyer is not limited by age, because to be able to buy legal liquor (class A, B and C) with expensive prices is not affordable, while mixed liquor can be got with a fairly cheap price/affordable of Rp.15.000 to Rp 20.000 for each packaging bottles or plastic bags (Kompas Newspaper dated May 6th, 2018).

The liquor victims in general are productive citizens aged 20 to 50 years old of average coming from the middle to lower class. Prevention efforts that can be done is by supervising and controlling the circulation of liquor to the level of the community environment in the form of participation to immediately report to the authorities if there is a circulation of alcohol or drinking activity so that the government and the authorities can act immediately after receiving reports from the community, then the perpetrators, makers and dealers must be punished/given severe sanctions to provide a deterrent effect and the sale of chemicals should be more controlled the circulation in order to narrow the access in the wider community considering the impact of abuse of mixed liquor is very concerned with the number of casualties.

\section{THE CONCEPT OF LAW ENFORCEMENT AND CRIMINAL PUNISHMENT}

Law is a compelling law but not for imposing on anyone but to protect human interests in society [5], [6]. Law as the norm is a guide for human life in the community about what to do and which should not so that everything can run in orderly. Van Kan states that the law is:

According to [3], all life rules that are coercive in order to protect human interests in society.

Law is the concretization of the value system prevailing in society, therefore it is the moral reference for solving legal cases that have no legal basis or no clear legal basis. Law renewal brings the consequences of a change of law that changes the value aspect underlying a legal system and brings influence to the substantive aspect (Soekanto 1982: 159). Whereas law enforcement is a process for making efforts to enforce legal norms in real terms as a code of conduct in community life, nation and state.

Every legal norm contains provisions regarding the rights and obligations of legal subjects but in law enforcement, according to [4] there are several influencing factors, namely:

1. The legal factor itself is the Law,

2. Law Enforcement Factors,

3. Facilities factors,

4. Cultural factors.

Data from informants in the field shows that the spread of alcohol abuse leads to social problems that arise in the community and cannot be separated from individual factors, this is where the state must attend to provide comfort for people's lives, which is precisely the legal umbrella regarding the production and trade of liquor although there is a Presidential Regulation No. 3 of 1997, but due to the emergence along with the phenomenon of regional autonomy, it had an impact on the awareness to issue a regional regulation prohibiting alcoholic beverages which created resistance and led to the cancellation of the Presidential Regulation by the Supreme Court and then replaced with Presidential Regulation No. 74 of 2013. The existence of the Perpres was considered ineffective, because alcoholic drinks did not bring benefits to the social life of the nation and were contradictory to the 1945 Constitution in guaranteeing the life of the nation and state.

On the other hand, there are those who regret that the trade in liquor must be removed and many parties fight for the law of the distribution and trade of alcoholic beverages closely related to customs, culture and tourism. Whereas what needs to be regulated is about limiting sales, place and time as well as consumer problems, namely those who can buy alcoholic beverages at least 21 years old. But in practice there have been many illegal alcohol sales in the form of mixed liquor and users of unlimited age (under 21 years).

The rampant abuse of alcoholic beverages in some areas has claimed many victims, demanding special attention from the government and law enforcement officials to minimize as quickly as possible through regulation or repression even though it has not been as extensive as handling drugs. The impact of abuse of liquor is not limited to physical and psychological disorders but also on social conditions, health, 
and public order until death. Therefore, it is necessary to take a law enforcement step by means of punishments, namely using criminal law as a sanction in the form of punishment because abuse of alcoholic drinks is related to humanitarian and social issues, as stipulated in Article 204 section (1) and (2), Article 300, Article 492, Article 536, Article 537, Article 538 and Article 539 of the Criminal Code.

Some of the above Article provisions can be concluded, that a liquor seller can be subject to Article 300 of the Criminal Code if intentionally selling, making drunk, forcing people to drink intoxicating drinks and if the act causes serious injury or death, with a maximum imprisonment of 1 (one) or a fine of Rp.4,500. Whereas for those who are drunk in public places, disturbing order and threatening the security of others can be charged under Article 492 of the Criminal Code with a maximum imprisonment of 6 (six) days or a maximum fine of Rp.375, -. Then the subject of Article 538 of the Criminal Code is a liquor seller who gives liquor to minors, with a maximum imprisonment of 3 (three) weeks or a maximum fine of Rp. 4,500, -

Of the three provisions of the article above, it is confirmed that the weak sanctions in law enforcement for those who use alcoholic beverages become deterrent. Therefore, it is necessary to take appropriate steps in dealing with the problem of alcohol abuse, among others by strengthening the role of the community's environment, optimizing regional regulations and law enforcement in an integrated unit of action between the National Police and the Regional Government (Municipal Police) by optimizing sanctions (criminal and fine) remembering victims abuse of alcoholic drink many died. Law enforcement should be able to provide a sense of justice and deterrent effects, for example by applying Article 340 of the Criminal Code concerning premeditated murder and/or Article 338 of the Criminal Code. In addition, as additional crimes can be imposed Article 137, Article 138 and Article 146 paragraph (1) letter b. Food Law, Consumer Protection Law and Health Law.

The implementation of alcoholic circulation and control law enforcement in the city of Semarang and in Grobogan Regency is carried out by the Civil Service Police Unit (Municipal Police) in accordance with its authority in implementing the Regional Regulation, through preventive and repressive efforts and always coordinating with local police officers as security organizers and public order.

As stated by the head of the legislative body in the city of Semarang, that: "The ranks of Municipal Police of Semarang City, in general have carried out law enforcement on the way of the Regional Regulation, especially regarding the supervision of the sale of alcoholic beverages, especially in the areas of East Semarang and North Semarang as a point of vulnerability".

Likewise, the Police apparatus in Semarang are in accordance with their duties and authorities, jointly carrying out safeguards during the joint operation of eradicating alcohol abuse along with the Municipal Police.

In law enforcement actions against alcoholic abusers (dealers and sellers), the National Police only imposes as a minor criminal act (Article 300 of the Criminal Code) with due observance to the provisions of Article 26 of Semarang
City Regulation 8 of 2009 concerning Supervision and Control of Alcoholic Beverages.

This condition is in line with the law enforcement provisions carried out by the regional government of Grobogan Regency along with the Grobogan Regency police in minimizing the circulation of liquor in the region. Whereas for prevention efforts according to the head of the legislative body of the Grobogan Regency, it is quite difficult to do considering that in the Kradenan village the community has a habit of traditionally producing white wine which is used as a mixture of herbal medicine/heating drugs. So that the task of the Regional Government together with the police is to carry out repressive actions that is giving direction and counseling about the dangers of alcohol abuse by involving community leaders to help monitor the circulation of liquor.

Another action taken is to conduct the inspection of liquor operations regularly and periodically by giving sanctions in the form of imposing minor criminal offenses for them (sellers, producers and users) of alcoholic beverages. Ironically the imposition of criminal sanctions does not have a deterrent effect because it is too mild and sometimes even only fined.

Generally, alcohol abusers are citizens at a productive age (20-50 years) therefore punishment is not to satisfy the absolute demands of justice, even though alcoholic victims fall a lot but prosecution is intended as a means to protect the interests of the community as well as to influence the public not to abuse alcohol. . The ultimate goal of criminal policy is community protection, so it must be able to integrate and harmonize all preventive activities by involving non-penal efforts in an integrated system. Non-penal efforts can be done by improving social conditions by strengthening the role of the community's environmental functions. Community involvement has a strategic position that must be intensified and streamlined because failure in the effort to overcome alcohol abuse will be fatal and disrupt public order.

As stated by Johannes Andenaes that in general prevention does not only include the influence of deterrent effects but also includes the influence of moral or social educational influences. Because people who abuse alcoholic beverages are from social circles middle to lower economies and low education they mix alcohol because they are simply unable to buy legal drinks that are expensive.

There are 3 (three) forms of influence in the sense of general prevention, namely:

a. Effect of prevention,

b. Influence to strengthen moral restrictions,

c. Influence to encourage customs of obedience to the law[2].

So punishment should be able to have the benefit of preventing the perpetrator from doing the crime (special preventive), preventing the general public from doing the crime (general preventive) and giving influence to strengthen the morality of the society and encourage the law-abiding behavior. Criminal also aims to scare (deterrence) perpetrators of crime and society to be deterrent and not to commit crimes[6].

The restoractive justice concept places an element of value in the involvement of the parties, in which the victim is 
expected to be able to restore the element of control and the perpetrator is encouraged to assume responsibility for correcting the crime caused by the crime. In the offense of alcohol abuse/liquor there is a certain prohibited circumstance and causal relationship, without any causal relationship between the consequences and the actions of the accused person causing the consequences can not be proven that the person who committed the offense to be accountable to him. On the other hand whether the necessary elements of deliberate and negligence.

The Criminal Code does not formulate "deliberate" specifically but in Article 18 of the Criminal Code it is expressly stipulated that: "Whosoever commits deeds by knowing and willing it, he does so deliberately".

In Memorie van Toelicting, the general penalty is to be imposed only on anyone who commits prohibited deeds with the desired and known, to think about is the consequences and circumstances that are accompanied, although there is a possibility that whenever possible do not desirable. So that if the defendant committed a criminal act with deliberation then chances are he did want the action or it could not be desired at all. Deliberation as a result is called intent as a certainty and if it is merely possible the possibility is deliberate as a possibility, consequently the defendant violates Article 338 of the Criminal Code (Moeljanto, 2002 : 178). By should be penalized by imprisonment for at most 15 (fifteen) years. The foregoing provisions are appropriate to be imposed on mixed liquor abusers by using hazardous substances considering the many casualties that fall from time to time continue to increase in number.

\section{CONCLUSION}

Alcoholic beverages (liquor) in Indonesia are not prohibited as long as they used it properly and not abused. In supervising and handling the problem of illegal liquor, coordination is needed between law enforcers (Municipal Police and Indonesian National Police) as well as community involvement, because any sanctions against the alcoholic abusers have no deterrent effect, so law enforcement must have a function of benefit, legal certainty and justice.

\section{REFERENCES}

[1] Moeljatno, Asas-Asas Hukum Pidana, Jakarta: Rineka Cipta, 2002, p. 178

[2] Muladi and Barda Nawawi Arief, Teori-Teori Dan Kebijakan Pidana, Bandung: Alumni, 1984, p.18

[3] R. Soeroso, Pengantar Ilmu Hukum, Sinar Grafika, 1993, p.54

[4] Soerjono Soekanto, Kesadaran Hukum Masyarakat, Jakarta: Rajawali, 1982, p. 159

[5] Sudarto, Hukum Pidana I, $2^{\text {nd }}$ Edition, Semarang: Yayasan Sudarto, Faculty of Law Diponegoro University, 1999, p.9

[6] Tommy Leonard, Pembaharuan Sanksi Pidana Berdasarkan Falsafah Pancasila Dalam Sistem Hukum Di Indonesia, Hukum Yustisia Journal, Faculty of Law Sebelas Maret University, 2016, p. 136

[7] Presidential Regulation of Republic of Indonesia No. 74 of 2013 on Control of Alcoholic Beverage

[8] Indonesian Criminal Code, KUHP

[9] Holistik Journal, Year VIII No. 16/July-December 2005, p.7.

[10] Kompas Newspaper May 6th, 2018

[11] Waluya Bagja, 2007, Menyelami fenomena Sosial di Masyarakat, (online) http://hmibecak.wordpress.com/2007/05/29/minuman-kerasremaja

[12] https://id.esdifferent.com/difference-between-ethanol-and-methanol

[13] https://health.detik.com/berita-detikhealth/d-3969907/sama-samaalkohol-ini-bedanya-etanol-dengan-metanol

http://budisma.net/2016/06/perbedaan-antara-etanol-dan-metanol.html 